Prof. Elizabeta Ristanovic, MS, $\mathrm{PhD}^{*}$

University of Defence, Belgrade

UDK - 343.326 : 616.9(093.2)(497.11)

Примљено: 29.09.2015

\title{
Infectious Agents as a Security Challenge: Experience of Typhus, Variola and Tularemia Outbreaks in Serbia
}

\begin{abstract}
The global community of today is confronted with serious threats from infective diseases, which can appear as naturally-occurring diseases, outbreaks and pandemics, or after deliberate misuse of the pathogens in the event of bioterrorist actions. There are about 2-3 million of various microorganisms in the Nature, and only about 5\% of them have been identified until now. In 2013 there were about 35 million people infected with HIV in 119 countries, and 1.5 million people died. The anthrax campaign of 2001 in the United States, as well as subsequent outbreaks of SARS, the avian flu and Ebola, along with the swine flu pandemic, show that microorganisms are a real threat with unforeseeable consequences for human health, the environment and society, and accordingly represent a serious security risk per se. Unlimited possibilities for manipulations that science and technology provide in this area instill fear of the possible abuse of the pathogens and their use in the war and bioterrorist acts, particularly in times of accumulated contradictions of modern civilization. Therefore, the development of co-operation strategies and precise definition of the roles and tasks of intelligence and security sector, police, military, public health sector and decision-makers in such circumstances as well providing of adequate resources for detection, identification, diagnostics and treatment of the agents and the diseases should be one of the main national tasks. International cooperation is also of paramount importance. This paper presents the experience and lessons from the large outbreaks that occurred in our geographic region in different historical periods: typhus, which caused great damage to Serbian army and people during World War I, the epidemic of smallpox in Yugoslavia in 1972 as the biggest postwar outbreak in Europe and the tularemia outbreaks in the area the former Yugoslavia in the 1990s. The infective agents causing these diseases are potential biological weapons.
\end{abstract}

Keywords: microorganisms, security, epidemics, bioterrorism, typhus, variola, tularemia.

*E-mail: elizabet@eunet.rs 


\section{Introduction}

The concept of security has evolved over time so that today it encompasses many different things including social development, environmental protection, public health, human rights, and other issues considered to be inalienable prerequisites of security. (Ban, 2003)

Although the human health significantly improved in the last century, thanks to the great progress in medicine, the global community continues to face the serious health threats, so we can estimate that these threats present one of the leading security challenges in the time we live in. Among them the infective diseases caused by various microorganisms (bacteria, viruses, fungi, parasites and toxins) have the leading position.

There are about 2-3 million of various microorganisms in the Nature, and only about $5 \%$ of these have been identified until now. According to the World Health Organization (WHO), the diseases caused by microorganisms are classified in the top ten leading causes of death in the world. Infectious diseases are responsible for the death of about 15 million people on the planet each year, and more than $50 \%$ of children under five years of age. Global AIDS epidemic is a serious problem. About 35 million people infected with HIV were registered in 119 countries in 2013, and 1.5 million people died. The epidemiological situation is particularly difficult in countries of subSaharan Africa, where actually $71 \%$ of the infected live. (WHO, 2014) While scientists have been looking for the explanation of the virus origin, the routes of its transmission and the ways of treatment, much as fast as the conspiracy theories have been also spreading, including those that the virus was created in the laboratory as a biological weapon (BW) in order to destroy the black race and the gays, that there were the financial interests of the pharmaceutical industry behind the appearance of HIV because the medications are extremely expensive, etc.

It is considered that more than $15 \%$ of all malignant diseases have infectious etiology. The highest percentage of infectious diseases was recorded in the countries of Africa (62\%) and the Southeast Asia (31\%), while the developed countries, after the eradication of traditional infective diseases are faced with the appearance of the new ones. It is also worth mentioning that about 2.3 billion of animal-borne infections afflict people every year. Due to the effects of global warming, the average air temperature in the $20^{\text {th }}$ century increased by $1.3^{\circ} \mathrm{C}$, air and water pollution increased, as well as the lack of drinking water, food and energy sources, thus facilitating occurrence of various infectious diseases. (Ristanovic \& Rakic, 2011)

The World Bank report has identified great outbreaks and pandemics as one of the major global risks, together with climate changes and financial crises. A Bank study found that spending $\$ 3.4$ billion annually would bring 
human and veterinary public health services in developing countries to reach the standards related to capacities for early detection, diagnosis and control of infective diseases. (World Bank, 2012)

Anthrax campaign in 2001 in the United States, as well as subsequent outbreaks of SARS, avian flu, Ebola, and swine flu pandemic show that microorganisms are a real threat with unforeseeable consequences for health, the environment and society, and accordingly represent a serious security risk per se. Unlimited possibilities for manipulations that science and technology provide in this area instill fear of the possible abuse of the pathogens and their use in the war and bioterrorist acts, particularly in times of accumulated contradictions of modern civilization.

Terrorism today is a global threat and one of the biggest security risks, be it a traditional or postmodern - superterrorism which involves the use of weapons of mass destruction (WMD) - biological, chemical, nuclear, radiological, with the addition of cyberterrorism. WMD have become the opponent that is hard to defeat, since they are relatively easily available, inexpensive, efficient, hardly recognizable, and their application in terrorism can increase their effects many times, getting unknown and uncontrollable dimensions. Among them, BW actually inspire the greatest fear, since they have been evolving formidably and expanding rapidly, especially in the era of genetic engineering and biotechnology. The potential destructiveness of BW is such that it is seen as a strategic threat, because it can produce a wide range of suffering and casualties. That is why it is important to understand the phenomenon of bioterrorism and its potential consequences, as well as to prepare the resources for an adequate response to bioterrorist attacks. National security strategies of most countries are inadequately developed in this segment: there are no clearly defined mechanisms of defence or the obligations of entities that should participate in the prevention and response to biological accidents and possible biological attacks. This task must be realized by a multi-sector and multidisciplinary approach, with the provision of adequate material resources and trained experts in different fields. (Ristanovic, 2015; Danicic M \& Maksimovic G, 2014)

This paper presents the experience of large outbreaks that occurred in our geographic region in different historical periods: typhus, which caused great damage to Serbian army and people during World War I, the epidemic of smallpox in Yugoslavia in 1972 and the epidemic of tularemia in the area of the former Yugoslavia during the civil war and aggression on our country in the 1990s. It is noteworthy that the infective agents causing these diseases are potential BW of the Class A (tularemia and smallpox) and Class B (typhus). 


\section{Typhus Epidemic as Enemy or Form of Biological War}

Typhus belongs to the group of rickettsial diseases that can be caused by the large number of bacteria that can be transmitted by various vectors (lice, fleas, mites, ticks). Typical symptoms and signs of rickettsial diseases include the onset of high fever, myalgia and headache, and skin rash with inoculation lesion. The typhus causative agent is Rickettsia prowazekii. Epidemic typhus was described in the Ancient Greece in the $5^{\text {th }}$ century BC. In the New World typhus was first described in Mexico in 1517. In this area about 2,000,000 Indians died of typhus. Disease was widespread in Europe, especially in times of war. In Russia about 3,000,000 people died of typhus in the period

1918-1922.

(http://entomology.montana.edu/historybug/wwi/tef.htm) The first outbreak in the Balkans was recorded in the $16^{\text {th }}$ century. During the First World War the disease killed about 150,000 or even 200,000 people in Serbia. All 595 Serbian doctors had been ill and 122 of them died. This typhus outbreak in Serbia was among the largest in the world. (http://entomology.montana.edu/historybug/typhus-conlon.pdf) Since then, there has been intense discussion of how it occurred and whether just poor hygienic conditions in the war contributed to the emergence of the disease, which sheds new light on the consideration of major epidemics in terms of security challenges and risks. The study of public health showed that typhus was not registered in Serbia in 1912. Pediculosis was suppressed and there was constant control. In the Serbian army typhus was recorded in the First Balkan War, in Edirne, as sporadic disease. Dr Kosta Todorovic found that Turkish prisoners were the source of infection. (Todorovic, 1957) On the other hand, in the Austro-Hungarian army, the problem of combating the typhus spread in the wars was a continuous task, due to the constant hot spots in Poland and parts of Bosnia and Herzegovina, around Tuzla. Military conscripts were living in the local community with frequent pediculosis. Recruits were expanding disease far from their homeland. Among the AustroHungarian soldiers who participated in the battles in Serbia in August 1914, there were the carriers of typhus who began to show signs of disease in late autumn. All of them were placed in the conquered war hospital in Valjevo. After the victory in the Battle of Kolubara, Serbian troops liberated Valjevo and found many wounded and patients with typhus in the hospital. Only several Czech doctors and paramedics took care of them. Serbian medics found 150 corpses in a basement, and those were people who died of typhus and lay there unburied for a few days. Then a huge number of Serbian refugees arrived in Valjevo. There was not enough space for their adequate sanitary protection, which led to the pediculosis emergence, and the first cases of typhus. Relocation of the refugees in the interior of the country gave 
rise to the devastating typhus epidemic that broke out in December 1914. Physically exhausted Serbian soldiers and refugees, women, children and the elderly, due to the lack of laundry, unsanitary housing and inadequate nutrition massively fell ill and died. Small number of Serbian doctors, mostly educated in the most prestigious medical centers in Europe, made enormous efforts to take care of the sick and wounded, pointing to the urgent need for the help of foreign experts. At that time only a Russian surgical team worked with them. It arrived in August of 1914 to assist in taking care of many wounded in the Battle of Cer. Serbian authorities addressed the Allies for help and the French medical mission soon arrived with about one hundred members. The British mission was led by Colonel, doctor Hunter and had 25 members who came with the order of their government to focus on the typhus epidemic and find measures to prevent its spread. Dr Hunter's recommendations resulted in the famous "Serbian Barrel", and two medical trains that served as mobile disinfection centers, stopping the spread of the disease in central Serbia in two weeks' time. (http://www.rastko.rs/cms/files/books/4d5045b8f2237) Dr Hunter wrote: "The 1914/15 typhus epidemic in Serbia was the most sudden to emerge, the fastest to spread, the greatest in intensity, and the fastest-stopped epidemic in history." He also noted that the "typhoid epidemic in Serbia is an example of inadvertent bacteriological warfare, as the Austrian Army from Bosnia had a lot of carriers in its ranks and that the Austrians concentrated the 3000 diseased in the Valjevo hospital, with malicious purpose." (Hunter, 1919) Dr Richard Strong, head of a US medical mission concluded that "the epidemic of typhus that took place in Serbia in 1915 was one of the scariest in the modern world"(Strong, 1920). The epidemic was stopped thanks to the brilliant medical proposals for prevention, the government competence and the citizens' responsibility in implementing them. During the Second World War typhus took a large number of victims among the Yugoslav soldiers and the people. Frequent occurrence of rickettsioses in war times can be the result of the poor hygienic and sanitary conditions (Zinnsser, 1935). However, the use of these agents as BW has always provoked special attention. During the period 1935-1945, Japanese researchers of BW conducted intensive research with rickettsioses, and experiments were made for this purpose with the aerosol dispersion of insects, possible rickettsial vectors, cultivation of mites, etc. Soviet and American experts thought that the rickettsial agents were most suitable for operational use as BW, and their use was suspected during the Korean War. Rickettsial species - R.prowazekii, R.typhi, R.rickettsii, O.tsustugamushi are now classified as Class B of potential BW. According to the WHO assessment in 1970, the hypothetical aerosol dissemination of 50 $\mathrm{kg}$ of typhus causative agent at a city of 500,000 inhabitants would cause the death of 19,000 and incapacitate 85,000 people. Otherwise, the lethality in 
this disease amounts to up to $30 \%$ in untreated patients. High infectiousness and contagiousness, diversified routes of transmission - through arthropod vectors, blood and aerosols, the lack of possibilities for rapid identification of Rickettsia spp. always and everywhere, clinical manifestations that often resemble other diseases, and the lack of effective vaccines, except for typhus, make rickettsial pathogens potential BW (Ristanovic et al, 2006). Intensive research efforts are being made in this area in order to develop efficient recombinant vaccines. In our geographic area, as stated above, R.prowazekii and typhus it causes, and its recurrence, Brill-Zinsser's disease were registered and documented, especially in war times. A large number of patients with typical symptoms of rickettsial diseases are registered each year, especially in the area of southern Serbia and the province Kosovo and Metohija, which were not etiologically confirmed as hemorrhagic fevers or other diseases, encouraged us a few years ago to begin the intensive investigations of seroprevalence of various rickettsial diseases at our geographic area. The results indicate that rickettsioses are present and that we must pay greater attention to them in the epidemiological, diagnostic and clinical sense (Samardzic et al, 2008).

\section{The Biggest Smallpox Outbreak in Post-War Europe}

Variola virus belongs to the family Poxviridae and represents the largest human virus (size about $400 \mathrm{~nm}$ ). The virus genome consists of the linear double-stranded DNA containing the information for the synthesis of about 200 proteins. Due to the genome size, it is difficult to make a synthetic viral copy. The virus has a complex structure and symmetry, with a lipoprotein envelope on the surface. It can be transmitted by aerosols and air droplets by direct contact with an infected person, as well as through contaminated water, food and objects. Smallpox is a highly contagious disease. Incubation lasts 12-14 days. The disease begins suddenly, with flulike symptoms, followed by the appearance of the characteristic rash, on the face, hands and forearms, and then on the torso. These lesions also occur on the mucous membranes, passing several stages, from maculopapular rash, via vesicles, then crusting to scabs. The disease cannot be transmitted from infected persons during incubation. They are most contagious during the temperature rise, in the first week of the rash appearance. The treatment of smallpox can be symptomatic and vaccination can be used (http://www.bt.cdc.gov/agent/smallpox/disease). The smallpox vaccine was the first vaccine in human history. It was prepared in the late $18^{\text {th }}$ century by English country doctor Edward Jenner who noted that women infected with cowpox did not catch smallpox. This immunization was first applied in 1796 saving one boy from the deadly disease. Jenner's method opened the way for 
vaccination launched by WHO in the $20^{\text {th }}$ century, thanks to which smallpox was officially eradicated in 1979 (WHO, 1980). It is important to emphasize that the vaccine against smallpox can also be applied in the post-exposure stage which is very important in providing protective immunity. Otherwise, smallpox is considered one of the most deadly diseases in human history. It first appeared in China and the Far East more than 3,000 years ago. Pharaoh Ramses V died of smallpox in 1157 BC. In Europe, it appeared in 710. At the time when the Spanish conquistadors conquered the New World, smallpox was used as a strong BW against the powerful empires of the Aztecs and Incas. When Hernan Cortes and his expedition landed on the coast of Mexico in 1519, aboard their boats were the goods infected with smallpox. The epidemic broke out very soon destroying nearly half of the indigenous population. In a similar way, Francisco Pizarro conquered the Inca empire (Simon \& Cappel, 2007). In the early $18^{\text {th }}$ century, smallpox annually killed about 400,000 citizens in Europe, including five rulers. During the large epidemics in Serbia in the period from 1896 to 1910, about 38,953 persons died. It is assumed that in the $20^{\text {th }}$ century between 300 and 500 million people died from smallpox (Riedel, 2005).

Just in a period of intense campaign for eradication of smallpox the epidemic occurred in Yugoslavia in 1972, the largest post-war outbreak in Europe. Both then and now, there were doubts and speculation that it might have been a bioterrorist attack against Tito's Yugoslavia, although scientific facts do not support this claim. The epidemic affected a total of 175 persons, and $35(20 \%)$ of them died. Among the patients there were $99(56.6 \%)$ men and $76(43.4 \%)$ women. Most patients were registered in the Republic of Serbia (174 ill persons, 124 of them in the province of Kosovo and Metohija and 1 person in Vojvodina; 35 people died, 26 of them in the province of Kosovo and Metohija and 1 person in Vojvodina), while in Montenegro 1 person was ill. An outbreak was detected on March 14, 1972. The last case of smallpox in Yugoslavia had been recorded four decades before, in 1930, so that doctors did not have practical experience in the diagnosis, nor sufficient knowledge of the facts related to epidemiology and the fight against this quarantine disease. Therefore, the diagnosis was established late, although most of the patients in the first generation had typical clinical signs. Epidemiological and serological tests found that a pilgrim - Ibrahim Hoti from Danjane village near Djakovica brought smallpox in Yugoslavia. He visited Mecca and Medina (Saudi Arabia) with 24 other pilgrims from Kosovo and returned by bus through Iraq, where, at that time, there were more smallpox cases. Upon his return, the pilgrim, according to his own testimony, suffered from clinically undiagnosed disease (fatigue, chills, fever), and he also had several small pimples on his face. During the medical examination, a month later, the scars, as well as the traces of vaccination 
were not detected on his face and body, although the vaccination was performed in December, 1971, at the Institute for Health Protection in Skopje (Macedonia). All participants of the hajj were vaccinated against smallpox, but blood testing showed that 20 of them had no satisfactory antibody titer, which opened up a number of issues related to the flaws in implementing vaccination (Šuvaković et al, 1972). The measures for the control of travelers coming from infected areas were implemented, according to WHO guidelines. The pilgrims were treated as a particularly risky group, so it was required to go on a pilgrimage in an organized manner, by plane, with presanitation, health control during the trip, as well as health surveillance after the return, which was generally enforced, in agreement with the Islamic community, but private arrangements were nevertheless organized, such as this one when the person who travelled brought the disease. All pilgrims stated they had been healthy during the trip. They were revaccinated during the epidemic. Serological examinations were performed after that at the Institute "Torlak" in Belgrade, the national reference laboratory for smallpox, and confirmed in CDC laboratories for smallpox in Atlanta (USA) (Bordjoski et al, 1972). The epidemic in the province Kosovo developed in three generations. Numbers of secondary infections from one source were closely connected with the length and intimacy of contact between patients and vulnerable people, and depended on the clinical form and stage of the disease. Out of 175 patients, 105 of them $(60 \%)$ were previously vaccinated, $66(37.7 \%)$ were unvaccinated, while for 4 of them $(2.3 \%)$ vaccination status was unknown. It is necessary to emphasize the big difference in the fatality rate among previously vaccinated (8\%) and unvaccinated persons $(35 \%)$. Outside the hospital there were infected $52 \%$ or 91 people, while 84 patients $(48 \%)$ were infected in hospitals. There was an exception in the province Kosovo with a twofold increase among outhospital cases. Otherwise, a common feature of postwar smallpox epidemics in Europe is that most of the patients were infected in hospitals, while with the Yugoslav outbreak the situation was reverse. Another specific feature of the epidemic in the primary focus referred to the fact that the source of nosocomial infections, besides the infectious department, was the maternity ward, although the route of virus introduction into this ward has not been determined. The characteristic of the outbreak was a large percentage of the affected infants, 14 of them, or $8 \%$ of the total number of patients, which is the largest number of affected children in all postwar smallpox epidemics in Europe (www.nlm.nih.gov/nichsr/esmallpox/SmallpoxYugoslavia,1972).

Vaccination started on the $16^{\text {th }}$ of March, immediately after the diagnosis of disease. By the decision of the Federal Epidemiologic Commission, vaccination was extended to the entire population of Yugoslavia, so that the measure covered a total of 18 million people. The treatment with Marboran 
and vaccinia gamma globulin was also implemented. All medical institutions in the country undertook adequate measures to combat smallpox. Health surveillance of hot spots in the province Kosovo included the daily supervision of the population, temperature checking and examination of the skin and the oral mucosa. Risk contacts were retained in special quarantine institutions, but there were also quarantined individual households and whole villages. Restrictions on population movement from infected areas, the control of a vaccination success and prohibition of the public gatherings were widely applied measures. The efforts of specially formed anti-epidemic bodies at all levels, good organization of health services, support of the Yugoslav People's Army, the international solidarity and the WHO support contributed to the relatively rapid epidemic suppression. Otherwise, the smallpox epidemic occurred before the beginning of the tourist season, and its rapid suppression was also very important from that aspect. The health service in Yugoslavia was seriously prepared for the virus importation within an organization of fighting against quarantine diseases, and our experts were trained in laboratories in England and West Germany. The efficiency and results of our national laboratory were highly rated by the WHO. The public was informed by competent professionals about the spreading of disease and taken measures, and in the daily newspapers were published the adequate bulletins. The WHO was permanently informed about all facts, and their competent experts were invited to coordinate informing of the world public. Otherwise, the work and coordination of all management and state administrative bodies responsible for health affairs in Yugoslavia were at a high level. The Federal Executive Council followed the work and gave full support to the Federal Headquarters for the fight against smallpox, whose task was to collect and publish data about disease, coordinate the work of national and provincial headquarters, acquire and distribute vaccines and other means and take other measures based on the evaluation of epidemiological situation. With all the problems that occurred in the work, some organizational, technical and other weaknesses, and the lack of practical experience, we can say that the Yugoslav health service quickly and efficiently carried out the task of combating smallpox outbreak, which was large both in terms of the number of cases (175) and geographical dispersion (25 foci) causing a severe disruption of life and economy in the country (Ristanovic et al, 2014).

In this regard, we learned the lessons that, in order to enable health services to combat the quarantine and other infectious diseases, it is necessary to develop a unified medical doctrine, to strengthen the capacity for rapid laboratory diagnosis, provide facilities and special wards for isolation and treatment of quarantine diseases, strengthen the capacity of the Institutes for Health Care with the training of mobile teams for field work, 
constant strengthening of sanitary-epidemiological service and the sanitary inspection, monitoring the epidemiological situation in the world and the latest achievements in the field of science as well as the conditions for their implementation. It was emphasized that special atention should be given to education and training of personnel and health education of the population (Jakovljevic et al, 1972).

The smallpox virus is officially eradicated, and according to the official data it is kept only in two laboratories at the CDC, Atlanta, USA, and the Russian State Centre for Virology and Biotechnology (VECTOR) in Koltsovo, near Novosibirsk, Russia. However, there is a fear of its application as a potential BW. The virus is well studied and can be easily genetically modified in order to disable the vaccine effect or increase the virulence. It creates the stable aerosols. A large part of the world's population is sensitive to this virus, since the vaccination was stopped after the eradication, the mortality is high, and there is no specific therapy. Smallpox as a potential BW is seriously taken into account today and this can be supported by the fact that in the last years of the $20^{\text {th }}$ century in the United States and some other countries worldwide embarked on the intensive production of vaccine against smallpox (Henderson et al, 1999).

\section{Tularemia on the War Scene of the Former Yugoslavia}

Tularemia (rabbit fever, Francis disease, soldier's disease) is a zoonosis caused by the bacterium Francisella tularensis. It was first described in the United States in 1911 as "a plague like disease," of the California ground squirrel. Today, it is primarily a disease of the temperate zone of the northern hemisphere. About 500,000 cases are recorded annually. Reservoirs are mammals, rodents of the orders Lagomorpha and Rodentia, while the vectors can be ixodid ticks and other haematophagous insects. A man can be infected by contact with infected animals or their products, through contaminated food and water, via vectors or through inhalatory aerosols. General symptoms (headache, chills, fever, aching muscles and joints) appear after the incubation period, and then the specific clinical manifestations of disease that are diverse, depending on the way of bacterial entry into the human body. The most common are ulceroglandular (skin ulceration and swelling of local and regional lymph nodes), glandular, oculoglandular, oropharyngeal, gastrointestinal, pulmonary and typhoid (generalized, septicemic) forms of the disease, but sometimes other manifestations may occur. The disease is cured with antibiotics. An effective vaccine does not exist (WHO, 2007). The first human infection in the former Yugoslavia was described in 1947 when the bacterium was isolated from human material. The epidemics in Croatia and Slovenia in 1953 and 1968 affected 199 people and then tularemia in our 
area took its first victim. A reservoir and the source of the disease were rabbits. According to detailed epidemiological-epizootiological studies of professor Heneberg and his colleagues from the Military Medical Academy in Belgrade, the entire area of the former Yugoslavia is endemic region for tularemia (Heneberg, 1972). The disease later appeared sporadically. During 1994 in the region of Koprivnica, Croatia, ulceroglandular tularemia was registered in people who previously had a tick bite. Epidemics broke out in Bosnia and Herzegovina during 1995, in the area of Vlasic Mountain, in the demarcation line zone between the clashing armies, and the diseased were on both sides. The oropharyngeal tularemia was registered, and the sources of infection were infected rodents. In Serbia, the disease occurred sporadically, while the first outbreak was recorded, in Sokobanja region in late 1998. The oropharyngeal tularemia was the dominant form of the disease. The epidemic spread and lasted during 1999 and 2000 (Lako, Ristanovic, et al, 2001). The socio-political context of that time was characterized by the threat of bombing the country, and then the beginning of the aggression, so the extensive field research during this period could not be carried out. In early 1999 we isolated F.tularensis in the dead mice of the genus Apodemus from the area of the mountain Rtanj. It was the first isolate in Serbia, confirmed in the relevant reference laboratory in Munich (Ristanovic, 2002). During the summer of 1999 the outbreak of tularemia was recorded on the territory of the province Kosovo and Metohija, but because of the political situation on the ground, our experts had neither access nor relevant data about the number of patients. That was the period marked by the media manipulation and accusations of Serbian forces for biological aggression in Kosovo. Clear scientific facts and precise data, which we then presented about the absolute groundlessness of the previous statements were not accepted even in international scientific circles, but, finally, thanks to the intellectual honesty of German military medical experts the truth was brought to light in 2002. In an extensive epidemiological study they conducted, as members of KFOR forces directly involved in the diagnosis and treatment of tularemia, they confirmed our statements that there was not any kind of biological aggression from our side, but that the epidemic that started in the south of Serbia in late 1998 was spread to the territory of Kosovo. The findings were officially published in a scientific article in one of the world's most prestigious journals in the field of microbiology (Grunow \& Finke 2002). Smaller outbreaks of tularemia occurred in the southern Serbia in 2010 when in the Pčinja district 16 persons were affected, mostly children of preschool, elementary and high school. At the end of 2014, in the area of the municipality of Gadzin Han, an epidemic of tularemia was declared with 30 affected people. Due to the increasing number of rodent population tularemia in the period to mid-2015 also appeared in other parts of Serbia, in the natural foci of the disease, such 
as Stara and Suva mountains, Rtanj and Kopaonik. According to the Institute of Public Health of Kosovo, since 1999 to date there were 1,469 of recorded cases of tularemia. From 1 January to 10 February 2015, 206 cases of tularemia were registered, and the epidemic was declared. In the Republic of Macedonia, 13 cases of tularemia were officially confirmed in the central part of the country in March 2015 (Hestvik et al, 2015). Otherwise, although there is no documented data on the use of F.tularensis as a BW agent, or they are well-kept secret, it is known that epidemics were often war-time companions, from the battle of Stalingrad, to the conflicts in the former Yugoslavia. The epidemics of tularemia in war conditions can be explained by poor hygiene and sanitary conditions that facilitate the development of all diseases. Concerning the pathogens whose reservoirs are rodents, we must not forget that the rodent population has its own demographic principles, which refers to the demographic expansion that occurs every 10-15 years, so the microbes they carry and diseases they provoke are more frequent. To distinguish whether an epidemic occurs naturally or as a result of BW agents it is essential to use a prior knowledge of the epidemiological-epizootiological situation on the ground, as well as to apply the molecular-genetic differentiation of autochthonous bacterial strains and isolates from the epidemic. Tularemia as a potential BW has always been very attractive because of its low infectious dose, diverse routes of transmission, wide distribution in nature, the possibilities for aerosolization, diverse clinical manifestations, difficulties in detection, diagnosis and treatment, as well as the lack of vaccine. It is well known that teams of experts in the United States, Japan, Germany and the former Soviet Union have for decades worked on its development as a BW. According to the data of Ken Alibek, the efforts of the Soviet experts have resulted in the production of strains resistant to antibiotics and existing vaccines. According to WHO claims from the distant 1969 , the aerosol dispersion of $50 \mathrm{~kg}$ of virulent F.tularensis strain over the city of 5 million inhabitants would cause 250,000 people to become ill and around 19,000 deaths. The impacts of this agent today, in the era of biotechnology, would be even more devastating. F.tularensis also belongs to the class A of potential BW (Petersen \& Schriefer, 2005).

\section{Conclusions}

The global community nowadays continues to be confronted with serious threats from infective diseases, which appear either as naturallyoccurring diseases, outbreaks and pandemics, as demonstrated by the swine flu, HIV or Ebola crises, or after a deliberate misuse of the pathogens in the event of bioterrorist actions, which is also reality of the modern world and an actual threat. Thus microorganisms and infective diseases are one of the main 
health, security and financial challenges at the national and global level. Fighting them calls for a multi-disciplinary and multi-sectoral approach and teamwork, as well as intensive international cooperation and provision of adequate human and material resources for detection, identification and treatment of the diseases. Bearing in mind the possible consequences of infective agents and biothreats, development of co-operation strategies and precise definition of the roles and tasks of intelligence and security sector, police, military, public health sector and decision-makers in such circumstances are the national imperatives of time we live in.

\section{References:}

1. Ban, J. (2003) Health as a Global Security Challenge. Seton Hall Journal of Diplomacy and International Relations Summer-Fall. 1928

2. Bordjoški M, Stojković Lj, Gligić A, Bošković R, Stefanović Z, Pecić J, Petrović R. (1972). Laboratorijska dijagnostika variole za vreme epidemije 1972. godine. U Variola u Jugoslaviji. Izabrani materijali sa jugoslovenskog simpozijuma o varioli održanog $\mathrm{u}$ Primoštenu 21. do 24. novembra 1972. godine. str. 215-227 (In Serbian)

3. Danicic M, Maksimovic G. (2014) Profilisanje menadžera bezbjednosti za upravljanje kriznim situacijama. Bezbednost. God. LVI Broj 1; str.41-56

4. Grunow R, Finke EJ.(2002). A procedure for differentiating between the intentional

5. Henderson DA, Inglesby TV, Bartlett JG, et al. (1999) Smallpox as a biological weapon.

6. Heneberg, DJ. (1972) Istraživanje prirodnih žarišta tularemije i doprinos njihovom otkrivanju i prepoznavanju u SFRJ. Doktorska disertacija, Vojnomedicinska akademija, Beograd (In Serbian)

7. Hestvik G, Warns-Petit, Smith A, Fox J , Uhlhorn H , Artois M, Hannant D, Hutchings R, Mattsson R , Yon L , Gavier-Widen (2015) The status of tularemia in Europe in a one-health context: a review Epidemiol. Infect. 143: 2137-2160.

8. http://entomology.montana.edu/historybug/typhus-conlon.pdf (Conlon J. The historical impact of epidemic typhus)

9. http://entomology.montana.edu/historybug/wwi/tef.htm (Tschanz, DW. Typhus fever on the eastern front in World War I)

10. http://www.bt.cdc.gov/agent/smallpox/disease 
11. http://www.rastko.rs/cms/files/books/4d5045b8f2237 (Čekanac R, Mladenović J, Mikić D, Nedok A, Popović B. Istorijski osvrt na epidemiju tifusa u srpskoj vojsci 1914-1915.

12. https://www.nlm.nih.gov/nichsr/esmallpox/SmallpoxYugoslaviaEPI-72-91-2.pdf

13. Hunter W. (1919) The Serbian Epidemics of Typhus and Relapsing Fever in 1915, Their Origin, Course and Preventive Measures employed for their Arrest, Proceeding of the Royal Society of Medicine, XIII(2):30-158.

14. Jakovljević Dj, Vukmanović Č, Dovijanić P. (1972) Organizacija borbe protiv karantinskih bolesti u SFRJ u svetlu protekle borbe protiv variole. $\mathrm{U}$ Variola $\mathrm{u}$ Jugoslaviji. Izabrani materijali sa jugoslovenskog simpozijuma o varioli održanog u Primoštenu 21. do 24. novembra 1972. godine. pp. 253-259 (In Serbian)

15. Lako B, Ristanovic E, Prodanovic R, Spasic M, Djuric R. (2001). First epidemic of tularemia in FR Yugoslavia. The ASA NEWSLETTER.2001; 01-5(86):19-20

Medical and Public Health management. JAMA 281:2127-2137.

Odbrana Media Center, Belgrade. ISBN: 978-86-335-0458-4

16. Petersen J, Schriefer M (2005). Tularemia : emergence/reemergence.Vet.Res.36;455-467

Proceedings of The Third World Congress on Chemical, Biological and Radiological

release of biological warfare agents and natural outbreaks of disease: its use in analyzing

17. Riedel, S. (2005). Edward Jenner and the history of smallpox and vaccination. Proceedings (Baylor University. Medical Center). 18(1): $21-25$.

18. Ristanovic E (2002): Tularemija-vojnička bolest (savremena mikrobiološka dijagnostika tularemije) NIC Vojska, Beograd. ISBN 86-7530-057-3 (In Serbian)

19. Ristanovic E, Gligic A, Protic-Djokic V, Atanasievska S, Jovanovic D, Radakovic S. (2014) Smallpoxvirus - potential bioweapon and actual biothreat: ex-Yugoslav lessons. $19^{\text {th }}$ Congress Balkan Military Medical Committee, Plovdiv, Bulgaria, 7-10 ${ }^{\text {th }}$ May 2014. Abstract book. p.155 (awarded as best presentation)

20. Ristanovic E, Lako B, Samardzic S, Gligic A. (2006) Rickettsia sp. as potential BW.

21. Ristanovic E, Rakic U. (2011) Impact on Climate Change on Microorganisms. The European Journal of Management and Public Policy. 11(1):85-91 ISSN: 1726-6475

22. Ristanovic E. (2015). Bioterrorism:prevention and response. 
University of Defence/

23. Samardzic S, Marinkovic T, Marinkovic D, Djuricic B, Ristanovic E, Simovic T, Lako B, Vukov B, Bozovic B, Gligic A. (2008) Prevalence of antibodies to rickettsiae in different regions of Serbia. Vector-borne and zoonotic diseases. 8(2):219-224

24. Simon O, Cappel C (2007). The smallpox genocide of the Odawa tribe at L'Arbre Croche, 1763: the history of a Native American people. Lewiston, NY: Edwin Mellen Press. ISBN 0-7734-5220-6.

25. Strong, RP. (1920). Typhus Fever with Particular Reference to the Serbian Epidemic. Cambridge: Harvard University Press

26. Šuvaković V, Kecmanović M, Pavlović J, Mijušković P, Janković T. (1972) Klinička slika i iskustva u lečenju variole u Jugoslaviji 1972. godine. U Variola u Jugoslaviji. Izabrani materijali sa jugoslovenskog simpozijuma o varioli održanog u Primoštenu 21. do 24. novembra 1972. godine. pp. 95-101 (In Serbian)

Terrorism.Dubrovnik, Croatia, p.268-275.

the tularemia outbreak in Kosovo in 1999 and 2000. Clin Microbiol Infect. 8:510-21.

27. Todorović K. (1957) Uspomene na epidemiju pegavca iz 1914-1915. godine, Zbornik osnivačke skupštine Jugoslovenskog društva za istoriju medicine, farmacije i veterine, Beograd

28. WHO (1980) The Global Eradication of Smallpox: Final Report of the Global Commission for the Certification of Smallpox Eradication. Geneva: World Health Organization; 1980. Global Commission for Certification of Smallpox Eradication.

29. WHO (2007). WHO Guidelines On Tularemia

30. WHO (2014) World Health Statistics 2014

31. World Bank (2012) People, Pathogens and our Planet; The economics of one health.

32. Zinnsser, H. (1935) Rats, Lice \& History. Boston: Little, Brown \& Company.

\section{Infektivni agensi kao bezbednosni izazov: Iskustva iz epidemija tifusa, variole i tularemije u Srbiji}

Apstrakt: Mikroorganizmi i infektivne bolesti koje izazivaju predstavljaju jedan od najvećih zdravstvenih, ekoloških, socio-psiholoških, finansijskih i bezbednosnih rizika današnjice, bez obzira da li se javljaju sporadično, u formi epidemija $i$ pandemija, ili su rezultat namerne zloupotrebe patogena u eventualnim bioterorističkim napadima što je danas aktuelni bezbednosni rizik globalnih razmera. Zato je razvijanje precizne strategije prevencije i regovanja u slučaju takvih pojava sa jasno definisanim 
zadacima i obavezama obaveštajno-bezbednosnog sektora, policije i vojske, medicinskog $i$ veterinarskog sektora, kao i donosilaca odluka prvorazredni nacionalni zadatak, uz obezbeđivanje adekvatnih ljudskih $i$ materijalnih resursa $i$ uspostavljanje međunarodne saradnje u ovoj oblasti. $U$ radu su predstavljena naša iskustva i lekcije iz velikih epidemija koje su se dešavale kod nas u različitim istorijskim periodima, poput epidemije tifusa koji je u vreme Prvog svetskog rata naneo ogromnu štetu srpskoj vojsci i narodu, epidemija variole 1972. godine koja se smatra najvećom epidemijom u posleratnoj Evropi, kao i epidemije tularemije na području nekadašnje Jugoslavije krajem 90-tih godina prošlog veka. Izazivači svih navedenih bolesti mogu se koristiti i kao biološki agensi.

Ključne reči: mikroorganizmi, bezbednost, epidemija, bioterorizam, tifus, variola, tularemija 